League Council has insisted that decision upon these exercises of sovereign powers can only be made by the mandatory with consent of the League Council. These cases thus seem to support the present writer's suggestion that "there will be a close approach to truth in ascribing sovereignty of mandated territories to the mandatory acting with the consent of the Council of the League." 48 It appears that these two acting together can, in fact, determine the status of either inhabitants or territory of the mandated areas.

QUINCY WRIGHT.

\title{
THE SETTLEMENT OF OUTSTANDING CLAIMS BETWEEN MEXICO AND THE UNITED STATES
}

On September 8, 1923, a Convention for the Settlement of General Claims between Mexico and the United States was signed at Washington on behalf of the United States by Charles Evans Hughes, Secretary of State; Charles Beecher Warren, former Ambassador of the United States to Japan, and John Barton Payne, former Secretary of the Interior; and on behalf of Mexico by Manuel C. Téllez, Chargé d'Affaires ad interim of Mexico at Washington. The ratification of the treaty was advised by the Senate on January 23, 1924; ratified by the President of the United States on February 4, 1924; ratified by Mexico on February 16, 1924; ratifications exchanged at Washington on March 1, 1924, and proclaimed on March 3, 1924 . The convention, therefore, is a law both of the United States and of Mexico, the origin, the source and the measure of the general claims of the United States against the sorely tried Republic of Mexico.

The two countries had in mind a settlement of all outstanding claims, and as a part of the transaction a Special Claims Convention was negotiated for the settlement of claims of American citizens arising from revolutionary acts in Mexico from November 20, 1910, to May 31, 1920. This convention was signed in the City of Mexico on September 10, 1923, and, going through the various stages required by the laws of both, was proclaimed as law by the President of the United States on February 23, 1924. It is, therefore, the law of the two Republics, and, like the general convention, it is the source and measure of the special claims for which it was negotiated, which the Government of the United States has by its terms the right to present against the Government of Mexico, and in appropriate cases to receive compensation. In this case the situation was reversed. George F. Summerlin, Chargé d'Affaires ad interim of the United States, acted on behalf of his country, and Alberto J. Pani, the Mexican Secretary of State for Foreign Affairs, signed on behalf of his country. Reciprocity was observed, in that the General Claims Convention was signed in Washington, the official residence of the Secretary of State of the United States, and the Special

4 This Jouranal, 17: 698. 
Claims Convention was signed in the City of Mexico, the official residence of the Secretary of State for Foreign Affairs of Mexico.

The scope of the General Claims Convention is, as its title indicates, broader than the other. On July 4, 1868, a claims convention was signed for the settlement of general claims of the two governments then outstanding. The purpose of the present convention is to submit to a commission claims of a general nature, arising since that period, so that with these claims settled and out of the way, there will be nothing of this kind outstanding to prejudice the friendly relations of the two Republics. It would be difficult to give a summary of the claims to be submitted, other than by the text of the article submitting them, which is in itself a summary. It therefore follows:

All claims (except those arising from acts incident to the recent revolutions) against Mexico of citizens of the United States, whether corporations, companies, associations, partnerships or individuals, for losses or damages suffered by persons or by their properties, and all claims against the United States of America by citizens of Mexico, whether corporations, companies, associations, partnerships or individuals, for losses or damages suffered by persons or by their properties; all claims for losses or damages suffered by citizens of either country by reason of losses or damages suffered by any corporation, company, association or partnership in which such citizens have or have had a substantial and bona fide interest, provided an allotment to the claimant by the corporation, company, association or partnership of his proportion of the loss or damage suffered is presented by the claimant to the Commission hereinafter referred to; and all claims for losses or damages originating from acts of officials or others acting for either Government and resulting in injustice, and which claims have been presented to either Government for its interposition with the other since the signing of the Claims Convention concluded between the two countries July 4, 1868, and which have remained unsettled, as well as any other such claims which may be filed by either Government within the time hereinafter specified, shall be submitted to a Commission consisting of three members for decision in accordance with the principles of international law, justice and equity.

If the matter stood here, it might seem that only claims arising before the signature of the convention could be submitted. This is, however, not so.

Leaving for the moment the composition of the commission, in order to determine the claims to be submitted, it is provided generally in the 6th Article that the claims shall be filed within one year of the first meeting of the commission; that all claims submitted shall be decided within three years of the first meeting of the commission, and that any particular claim presented shall be decided within six months after its presentation. This article, however, relates to claims already in being. Article 7 looks to the future, and therefore the contracting parties agree that either government may present a claim, arising after the signature of the convention at any time before the expiration of the three years during which the commission shall be in existence, and they further agree to prolong, if need be, the 
duration of the commission in order that any and all such claims presented within this period may be decided.

The commission is to be composed of three members: one appointed by Mexico, one by the United States, and upon the failure of the two governments to agree upon the third, who shall preside over the commission, he is to be appointed by the President of the Permanent Administrative Council of the Permanent Court of Arbitration at The Hague, in accordance with Article XLIX of the Pacific Settlement Convention of 1907. This is to be the method of appointing the third member of the commission in case of disagreement of the two contracting governments, and it calls to notice in an apt and pointed way the existence of the Pacific Settlement Convention, creating the so-called Permanent Court of Arbitration and organizing the diplomatic corps, accredited to The Hague, into an administrative council for the supervision of the Court of Arbitration. The Pacific Settlement Convention of the First Conference was revised and enlarged by the Second Hague Conference, meeting in 1907 . Therefore, in this apparently simple way, the two countries, neither of which is a member of the League of Nations, point to the Hague, which appears to many people of the day to be a terra incognita.

The commissioners are to meet in Washington six months after the exchange of ratifications of the convention, and each commissioner is to "make and subscribe a solemn declaration stating that he will carefully and impartially examine and decide, according to the best of his judgment and in accordance with the principles of international law, justice and equity, all claims presented for decision." When, however, the commission is organized it is empowered to meet, either in Mexico or the United States, subject of course to the approval of the contracting parties.

It is encouraging to see that the recent claims convention is in accordance with the first, which these United States ever concluded. In the Jay Treaty of November 19, 1794, the outstanding claims were to be decided "according to the merits of the several cases, and of justice, equity and the law of nations." There should be continuity in matters of justice. There is in this case at least.

There is, however, a novel provision connected with the jurisdiction of the commission which, it is to be hoped, will meet with general approval, for it would seem to settle a difficulty of no mean order in a spirit of goodwill and in the interest of justice. Secretary Hughes said, on opening the Armament Conference in Washington on the 12th day of November, 1921 , that the way to peace is the will to peace. He has carried into effect his precept, and fortunately the Mexican Government has confessed its faith in the will to peace as the way to peace in Article 5, which follows without comment or explanation, as it needs none:

The high contracting parties, being desirous of effecting an equitable settlement of the claims of their respective citizens thereby affording 
them just and adequate compensation for their losses or damages, agree that no claim shall be disallowed or rejected by the Commission by the application of the general principle of international law that the legal remedies must be exhausted as a condition precedent to the validity or allowance of any claim.

The commission must needs have rules, and, mindful of the principle of continuity, the convention provides as a standard, subject of course to modification, the rules of procedure of the Mixed Claims Commission under the convention between the two Governments of July 4, 1868. This is again a happy provision. It bridges the chasm between the two conventions, the latter taking up, as it were, where the former left off, adopting the same rules of procedure.

There is another novel provision in Article 9, to the effect that the commission shall award restitution of the property in question, if such action seems to be required by international law, justice and equity. In this case the government, taxed with restitution, is to restore the property, or if it prefers not to do so, the amount of compensation is to be fixed by the commission.

Finally, there is the usual barring clause, stated in a somewhat elaborate and unusual way. It is contained in the 8th Article and follows in full:

The high contracting parties agree to consider the decision of the Commission as final and conclusive upon each claim decided, and to give full effect to such decisions. They further agree to consider the result of the proceedings of the Commission as a full, perfect and final settlement of every such claim upon either Government, for loss or damage sustained prior to the exchange of the ratifications or the present Convention (except as to claims arising from revolutionary disturbances and referred to in the preamble hereof). And they further agree that every such claim, whether or not filed and presented to the notice of, made, preferred or submitted to such Commission shall from and after the conclusion of the proceedings of the Commission be considered and treated as fully settled, barred and thenceforth inadmissible, provided the claim filed has been heard and decided.

The Special Claims Convention has many points of similarity with the general convention, whose chief provisions have been mentioned. The commission is to consist of three members, appointed in the same manner (Article 1). In the interest of equity, the exhaustion of legal remedies is renounced (Article 6). The procedure, in so far as applicable, is to be that of the claims convention of July 4, 1868 (Article 4). As the labors of the commission for the adjustment of special claims are likely to be exacting, claims may be filed within two years of its meeting, and all claims are to be decided within five years, and each claim within six months of its presentation (Article 7). The barring clause also makes its appearance (Article 8). The special commission is, however, to be located in Mexico, to the convenience of all parties, within six months after the exchange of ratifications (Article 2). 
As is to be expected, there are some important differences between the two conventions, otherwise a single one would have sufficed. In the oath to be subscribed international law is omitted, and the decision of each claim is to be "in accordance with the principles of justice and equity." The reason for this omission is stated: The Mexican Government "ex gratia feels morally bound to make full indemnification and agrees, therefore, that it will be sufficient that it be established that the alleged loss or damage in any case was sustained and was due to any of the causes enumerated in Article III hereof."

Article 3, thus referred to, follows:

The claims which the Commission shall examine and decide are those which arose during the revolutions and disturbed conditions which existed in Mexico covering the period from November 20,1910, to May 31, 1920, inclusive, and were due to any act by the following forces;

(1) By forces of a Government de jure or de facto.

(2) By revolutionary forces as a result of the triumph of whose cause governments de facto or de jure have been established, or by revolutionary forces opposed to them.

(3) By forces arising from the disjunction of the forces mentioned in the next preceding paragraph up to the time when the government de jure established itself as a result of a particular revolution.

(4) By federal forces that were disbanded, and

(5) By mutinies or mobs, or insurrectionary forces other than those referred to under subdivisions (2), (3) and (4) above, or by bandits, provided in any case it be established that the appropriate authorities omitted to take reasonable measures to suppress insurrectionists, mobs or bandits, or treated them with lenity or were in fault in other particulars.

The claims to be submitted are those of citizens of the United States, arising within the specified period, "whether corporations, companies, associations, partnerships or individuals," and the actual legal or equitable interest of American citizens in each organization, is to be considered and compensation in appropriate circumstances awarded.

There is an identical provision in each of the conventions, to the effect that "the language in which the proceedings shall be conducted and recorded shall be Spanish or English." This may seem to be a small matter, but it is encouraging, as are so many provisions of the convention under consideration, to observe that the contracting parties are broad-minded in the question of language and permit the use of one or the other, as convenience dictates. The question of language to be used in international intercourse is one of convenience, and, rightly viewed, neither involves a renunciation of preeminence or superiority on the part of any Power. Nations must be on speaking terms. They should thus use in their intercourse on special and general occasions the language which is convenient to the nations at large. Precedents in this respect are so rare that it deserves more than a passing word of commendation when it exists. 
This modest comment will wholly fail of its purpose if it does not make clear that we are dealing with two conventions, incorporating the experience of the past with that new diplomacy based upon the will to peace as the way to peace, and as a prerequisite even to the will, mutual respect on the part of the contracting nations for one another.

JAMES Brown ScotT.

\section{A NOTE ON EXCHANGE V. M'FADDON}

In a classroom discussion of Exchange $v$. M'Faddon a student admitting the logic and cogency of Marshall's classic opinion objected that the result was not equitable. The Rambouillet Decree, he said, was contrary to international law, and certainly was of no validity within the territorial jurisdiction of the United States, and that $M^{\prime}$ Faddon and others were in a strange situation when a United States court failed to return to them property which had been illegally seized, and the title to which had never been divested under their country's laws. The objection gave opportunity for drawing attention to the legal principle that by the Rambouillet Decree and the consequent seizure of the schooner Exchange rights in international law in favor of the United States were invaded, that M'Faddon and his partner were not subjects of rights in international law but objects of them. The student continued to insist upon the essential lack of equity in such a situation, and fortunately in this case the record has been preserved which serves to show that ultimately justice was done to the owners of the schooner Exchange. Under the treaty with France of 1831 French spoliation claims including those under the Rambouillet Decree were presented, principal and interest amounting to $\$ 51,834,170.15$. Those recognized as prima facie falling within the treaty amounted to $\$ 41,640,838.35$. The total amount awarded was $\$ 9,352,193.47$. The amount paid by France was $\$ 5,558,108.07$, allowing dividends equal to $59.86 \%$ upon the various claims according to the award. Claim No. 371 made by Robert Barry, trustee of Eliza, Antoinette, and John M'Faddon, and Richard Caton, assignee of Gretham and Devereaux, each claiming a one-half interest in the schooner Exchange, Dye, master, seized December, 1809 , amounted to $\$ 54,566.81$. Barry and Caton were each allowed $\$ 19,501.47$. A record of these various transactions may be found in Sen. Ex. Doc. No. 417, 23d Cong., 1st sess.; Sen. Ex. Doc. No. 204, 24th Cong., 1st sess.; and H. Ex. Doc. No. 117, 24th Cong., 1st sess. These sums were paid to and receipted by Barry and Caton by treasury warrant as shown in Sen. Ex. Doc. No. 74, 49th Cong., 1st sess., p. 64. Perhaps this information may be of use to other teachers of international law who have students similarly sensitive to the equities lurking in this famous case.

J. S. REeves. 